\section{Бондаренко С.А.}

кандидат економічних наук, старший науковий співробітник

відділ економічного регулювання природокористування

Інститут проблем ринку та економіко-екологічних досліджень НАН України

Французький бульвар, 29, м. Одеса, Україна, 65044

\author{
Руммо В.В. \\ кандидат економічних наук, доцент \\ кафедра економічної теорії \\ та фрінансово-економічної безпеки \\ Одеська національна академія харчових технологій \\ вул. Канатна, 112, г. Одеса, Україна, 65039 \\ E-mail: etfeb@ukr.net
}

\author{
Нізяєва В.P. \\ магістрант \\ кафедра економіки підприємства \\ Університет державної фріскальної служби України \\ вул. Університетська, 31, м. Ірпінь, Україна,08201 \\ E-mail: viktoriyanizjaeva@gmail.com
}

\title{
АНТИКРИЗОВЕ РЕГУЛЮВАННЯ ЕКСПОРТНО-ІМПОРТНОЇ ДІЯЛЬНОСТІ УКРАЇНСЬКОГО ВИНОРОБСТВА
}

У статті досліджено стан експортно-імпортної діяльності підприємств виноробної промисловості. На основі отриманих результатів виділено сучасні ризики, які необхідно враховувати при антикризовому регулюванні для забезпечення належного рівня експортної спроможності підприємств виноробної промисловості. Доведено, що регуляторний вплив на розвиток виноградарства та виноробства слід зосереджувати, з одного боку, на безпосередній роботі із споживачем, а з іншого - на реструктуризації імпорту країни інструментами державного менеджменту.

Ключові слова: експортно-імпортна діяльність, підприємства виноробної промисловості, ємність ринку, ступінь відкритості ринку вина, антикризове регулювання.

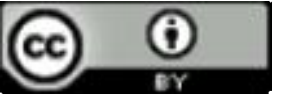

This work is licensed under a Creative Commons Attribution 4.0 International License http://creativecommons.org/licenses/by/4.0/
Постановка проблеми та її зв'язок з важливими науковими та практичними завданнями. Нинішній етап розвитку вітчизняного виноробства характеризується глибокими кризовими явищами, які стали наслідком безсистемного державного менеджменту. За умов невирішених питань щодо лібералізації зовнішньоекономічної діяльності, особливої уваги потребує система комплексних заходів щодо підвищення конкурентоспроможності вітчизняного виробника. Забезпечити належний рівень ефективності експортноімпортної діяльності можливо лише за умови впровадження науково обгрунтованих механізмів, планомірного регулювання експортної спроможності підприємств виноробної промисловості засобами комплексної взаємодії сучасних управлінських інструментів. Актуальності набуває захист вітчизняного винороба від агресивної експансії зарубіжної винної продукції та розширення можливостей для вітчизняних виробників виходу на нові зовнішні ринки.

Аналіз останніх досліджень і публікацій. Дослідженням основних підходів до формування механізму антикризового регулювання діяльності підприємств присвячено багато праць вітчизняних та зарубіжних вчених, таких як В. Василенко [1], С. Коротков [2], 3. Шершньова [3] та ін. Дослідженнями про- блем виноробства займались ряд вітчизняних учених, серед них: А. Авідзба [6], Б. Буркинський [7], В.Кучеренко [8], О. Гаркуша [9], Т.Мостенська [10]. Деякі дослідники приділяють достатньо уваги розробленню маркетингових стратегій для виходу з кризи (Ю. Мельник [4], С. Ілляшенко [5] та ін.), хоча окремі питання щодо механізмів антикризового управління потребують удосконалення та подальшого розвитку. Зокрема, потребує подальших розвідок напрямок маркетингового управління та його ролі в антикризових заходах підприємства. Не дивлячись на значний науковий доробок вітчизняних науковців, вимагає додаткового дослідження питання інструментарію антикризового регулювання експортно-імпортної діяльності українського виноробства.

Формулювання цілей дослідження. Метою дослідження є виділення основних напрямків антикризового регулювання експортно-імпортної діяльності підприємств виноробної промисловості.

Виклад основних результатів та їх обгрунтування. Виноробство в різні часи свого розвитку переживало то підйоми, то падіння, проте завжди залишаючись традиційною високоприбутковою галуззю в агропромисловому комплексі України. Нинішній етап розвитку галузі характеризується глибоким 
кризовим становищем, тому вимагає системної оцінки і дієвих заходів на усіх рівнях регулювання.

Виробництво вина в Україні та його споживання постійно скорочуються. Основні тенденції розвитку виноробної галузі можна дослідити на прикладі ігристих вин, оскільки їх виробництво значно менше залежить від імпорту. Згідно даних статистики, цей сегмент винної продукції представлений переважно вітчизняними виробниками. Частка імпортного шампанського у загальній структурі ринку ігристих вин є незначною та, за експертними оцінками, не перевищує $5 \%$ [9]. Згідно даних асоціації «Виноградарі й винороби України» за підсумками 2015 року, випущено не більше ніж 2,9 млн дала вина. В наступному році падіння - ще на 30-35\% (виробництво близько 1,5 млн дал). Падіння виробництва 2015 року, порівняно з 2014, становить близько 33\% [11].

Спостерігається яскраво виражена негативна динаміка виробництва виноробної продукції в Україні (табл. 1).

Динаміка виробництва виноробної продукції в Україні, тис. дал. [12]

\begin{tabular}{|l|c|c|c|c|c|}
\hline \multicolumn{1}{|c|}{ Показники } & 2011 & 2012 & 2013 & 2014 & 2015 \\
\hline Коньяк, бренді & 4709 & 4611 & 4548 & 2613 & 2971 \\
\hline $\begin{array}{l}\text { Вино ігристе із свіжого винограду } \\
\text { (крім вина "Шампанське") }\end{array}$ & 5460 & 5466 & 5357 & 3645 & 4754 \\
\hline 3 нього вино ігристе "Шампанське України" & 3741 & 3288 & 3136 & 2644 & 3237 \\
\hline $\begin{array}{l}\text { Вино, з фактичною концентрацією спирту не більше 15\% } \\
\text { (крім газованого, ігристого, та вина із } \\
\text { захищеним позначенням походження) }\end{array}$ & 11434 & 8610 & 7316 & 4748 & 6685 \\
\hline $\begin{array}{l}\text { Вино 3 концентрацією спирту більше 15\% (Портвейн, Ма- } \\
\text { дера, Херес та інші) }\end{array}$ & 5326 & 4035 & 4280 & 2409 & 1200 \\
\hline $\begin{array}{l}\text { Виноградне сусло (крім виноградного сусла, бродіння яко- } \\
\text { го зупинене шляхом додання спирту) }\end{array}$ & 9744 & 9370 & 17451 & 11373 & 12368 \\
\hline
\end{tabular}

Хоча статистичні дані указують на зростання у сегменті виробництво ігристих вин, проте реальний стан речей $є$ досить песимістичний. Загальний об'єм випущеної продукції залишається критично низьким iз тенденцією до скорочення. За даними Держстату України, за останні роки (2011-2015 рр.) виробництво виноградних вин знизилося на $62 \%$, досягнувши обсягу виробництва 2001 року. Показники 2015 року демонструють невелике падіння у порівнянні 3 даними 2014-го року. Можна припустити, що материкові підприємства скористалися нішею, яка утворилася за відсутності кримських виробників. Загальний кризовий стан економіки України має найбільший вплив на зниження обсягів виробництва ігристих вин і шампанського вітчизняними виробниками. Крім того, значне падіння купівельної спроможності населення знижує попит, що неминуче відображається на доходах виробників і на загальній кон`юнктурі ринку. Важливим негативним чинником останніх років $є$ втрата традиційних ринків збуту у зв`язку з політичною нестабільністю. Відчувається непідготовленість підприємств до революційних трансформацій для виходу на європейські ринки, що неминуче має негативний вплив на розвиток підприємств галузі. Дана галузь у значній мірі залежить від державного регулювання. Натомість, можна констатувати кризу державного менеджменту, яка виражається: (1) скасуванням 3 2013 року 1,5 відсоткового збору на розвиток садівництва, виноградарства та хмелярства, (2) безсистемною акцизною політикою, (3) запровадженням непомірної суми оплати у розмірі в 500 тисяч гривень за ліцензію на оптову торгівлю виноробною продукцією (яку, до речі у 2016 році було реформовано - лише для виробників, які працюють на закупівельних ви- номатеріалах), (4) збільшенням ставок земельного податку під багаторічними насадженнями у 33 рази, (5) загальною лібералізацією імпорту агропромислової продукції Україна.

На сьогодні Одеська область вважається виноробним регіоном України, оскільки тут працює близько 66\% виробників виноградних вин України. Однією з тенденцій розвитку галузі є скорочення частки шампанських вин у загальній структурі виробництва ігристого вина (з 2008 по 2013 рр. частка вина «Шампанське» скоротилася з 73,20 \% до 62,18 \%). Це насамперед пов'язано 3 тим, що провідні виробники ігристих вин, значна частина потужностей яких зорієнтована на експорт, поступово відмовляються від звичної назви вино «Шампанське», оскільки остання, відповідно до чинного законодавства, може використовуватися лише при реалізації продукції на внутрішніх ринках. Деякі виробники ігристих вин, задля відповідності тенденціям світового винного ринку, повністю перейшли на нову назву «вина ігристі», незважаючи на високі маркетингові ризики.

Аналіз виробництва ігристого вина і шампанського в розрізі компаній-виробників яскраво демонструє високу конкуренцію на ринку ігристого вина в Україні. Серед вітчизняних виробників ігристих i шампанських вин на статус загальнодержавних претендують лише два підприємства, продукція яких представлена у більшості регіонів країни - ПрАТ «Артемівськ Вайнері» (торговельні марки «KRIMART», «Крим», «Артемівське») та ПрАТ «Київський завод шампанських вин «Столичний» (торговельні марки «Наш Київ», «Українське», «Советское Шампанское», «Советское Преміум», «Мускат Ігристий», «Кримград», «Cuvée №1», «Henkell», «Fürst von 
Metternich», «Söhnlein Brillant»). Розуміючи складну економічну ситуацію в Україні, більшість компаній розширюють свій портфель продукції новими недорогими торговими марками ігристого вина і шампанського.

Експортно-імпортна діяльність має значний вплив на стан і розвиток підприємств виноробної промисловості.

У табл. 2 представлено динаміку імпортуекспорту продукції виноробства України за 20112017 pp.

Таблиця 2

Сумарний обсяг імпорту та експорту товарної позиції (УКТЗЕД) 2204 «Вина виноградні; сусло виноградне» за період 01.01.2011 по 31.07.2017*

\begin{tabular}{|c|c|c|c|c|c|c|c|c|c|}
\hline \multirow[b]{2}{*}{ Рік } & \multicolumn{4}{|c|}{ Імпорт } & \multicolumn{4}{|c|}{ Експорт } & \multirow[b]{2}{*}{$\begin{array}{l}\text { Сальдо, } \\
\text { тис. дол }\end{array}$} \\
\hline & $\begin{array}{l}\text { вартість, } \\
\text { тис. дол. }\end{array}$ & $\begin{array}{l}\text { питома } \\
\text { вага, \% }\end{array}$ & $\begin{array}{c}\text { вага нетто, } \\
\text { т }\end{array}$ & $\begin{array}{c}\text { ціна, } \\
\text { тис. дол. }\end{array}$ & $\begin{array}{l}\text { вартість, } \\
\text { тис. дол. }\end{array}$ & $\begin{array}{l}\text { питома } \\
\text { вага, \% }\end{array}$ & $\begin{array}{c}\text { вага нетто, } \\
\text { т }\end{array}$ & $\begin{array}{c}\text { ціна, } \\
\text { тис. } \\
\text { дол. }\end{array}$ & \\
\hline 2011 & 105925 & $0,13 \%$ & 63080 & 1,7 & 45121 & $0,07 \%$ & 40432 & 1,1 & -60804 \\
\hline 2012 & 105596 & $0,13 \%$ & 47960 & 2,2 & 51189 & $0,07 \%$ & 50669 & 1,0 & -54407 \\
\hline 2013 & 126922 & $0,17 \%$ & 50750 & 2,5 & 70860 & $0,11 \%$ & 70101 & 1,0 & -56062 \\
\hline 2014 & 95906 & $0,18 \%$ & 40175 & 2,4 & 40734 & $0,08 \%$ & 50998 & 0,8 & -55172 \\
\hline 2015 & 56492 & $0,15 \%$ & 29000 & 1,9 & 38173 & $0,10 \%$ & 64202 & 0,6 & -18319 \\
\hline 2016 & 85279 & $0,22 \%$ & 52063 & 1,6 & 24705 & $0,07 \%$ & 35048 & 0,7 & -60574 \\
\hline $\begin{array}{c}2017 \\
\text { (за } 7 \text { місяців) }\end{array}$ & 46418 & $0,17 \%$ & 22696 & 2,0 & 17621 & $0,07 \%$ & 23729 & 0,7 & -28797 \\
\hline
\end{tabular}

* складено авторами за даними Державної фіскальної служби України [12]

Україна у 2016 році імпортувала виноградного вина у 3,5 разів більше за експорт (у доларовому еквіваленті). Вже за 7 місяців 2017 року видно, що тенденція зберігається (імпорт перевищує експорт у 2,7 разів). При чому ціна імпорту перевищує ціну експорту у 2016-2017 pp. відповідно у 2,3 і 2,8 разів.

У табл.3 представлена географічна структура імпорту-експорту товарної позиції 2204 «Вина виноградні; сусло виноградне».

Таблиця 3

Географічна структура імпорту-експорту товарної позиції 2204 «Вина виноградні; сусло виноградне» за період 01.01.2011 по 31.07.2017 [12]

\begin{tabular}{|c|c|c|c|c|c|c|}
\hline \multirow[b]{2}{*}{ Рік } & \multicolumn{3}{|c|}{ Імпорт } & \multicolumn{3}{|c|}{ Експорт } \\
\hline & країна & 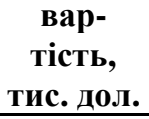 & $\begin{array}{l}\text { питома } \\
\text { вага,\% }\end{array}$ & країна & $\begin{array}{l}\text { вартість, } \\
\text { тис. дол. }\end{array}$ & $\begin{array}{l}\text { питома } \\
\text { вага, \% }\end{array}$ \\
\hline \multirow{4}{*}{2011} & Грузія & 23226 & 21,92 & Російська Федерація & 29794 & 66,03 \\
\hline & Молдова, Республіка & 22442 & 21,19 & Країни СНД & 4343 & 9,63 \\
\hline & Італія & 19067 & 18,00 & Німеччина & 3979 & 8,82 \\
\hline & Інші & 41191 & 38,89 & Інші & 7005 & 15,52 \\
\hline \multicolumn{2}{|r|}{ Всього } & 105925 & 100 & & 45121 & 100 \\
\hline \multirow{4}{*}{2012} & Грузія & 28255 & 26,76 & Російська Федерація & 39429 & 77,02 \\
\hline & Італія & 22064 & 20,89 & Країни СНД & 4092 & 7,99 \\
\hline & Франція & 19185 & 18,17 & Німеччина & 3138 & 6,13 \\
\hline & Інші & 36093 & 34,18 & Інші & 4531 & 8,85 \\
\hline \multicolumn{2}{|r|}{ Всього } & 105597 & 100 & & 51189 & 100 \\
\hline \multirow{4}{*}{2013} & Грузія & 32135 & 25,32 & Російська Федерація & 57716 & 81,45 \\
\hline & Італія & 28150 & 22,18 & Країни СНД & 3525 & 4,97 \\
\hline & Франція & 22993 & 18,12 & Грузія & 3469 & 4,90 \\
\hline & Інші & 43645 & 34,39 & Інші & 6150 & 8,68 \\
\hline & Всього & 126922 & 100 & & 70860 & 100 \\
\hline
\end{tabular}


Продовження табл.3

\begin{tabular}{|c|c|c|c|c|c|c|}
\hline \multirow[b]{2}{*}{ Рік } & \multicolumn{3}{|c|}{ Імпорт } & \multicolumn{3}{|c|}{ Експорт } \\
\hline & країна & $\begin{array}{c}\text { вар- } \\
\text { тість, } \\
\text { тис. дол. }\end{array}$ & $\begin{array}{l}\text { питома } \\
\text { вага, \% }\end{array}$ & країна & $\begin{array}{l}\text { вартість, } \\
\text { тис. дол. }\end{array}$ & $\begin{array}{c}\text { питома ва- } \\
\text { га, } \%\end{array}$ \\
\hline \multirow{4}{*}{2014} & Італія & 23534 & 24,54 & Російська Федерація & 29983 & 73,61 \\
\hline & Грузія & 21168 & 22,07 & Грузія & 4329 & 10,63 \\
\hline & Франція & 15741 & 16,41 & Країни СНД & 2468 & 6,06 \\
\hline & Інші & 35462 & 36,98 & Інші & 3954 & 9,71 \\
\hline \multicolumn{2}{|r|}{ Всього } & 95906 & 100 & & 40734 & 100 \\
\hline \multirow{4}{*}{2015} & Італія & 16851 & 29,83 & Російська Федерація & 26368 & 69,08 \\
\hline & Франція & 10987 & 19,45 & Грузія & 3264 & 8,55 \\
\hline & Грузія & 7926 & 14,03 & Країни СНД & 3234 & 8,47 \\
\hline & Інші & 20729 & 36,69 & Інші & 5306 & 13,90 \\
\hline \multicolumn{2}{|r|}{ Всього } & 56492 & 100 & & 38173 & 100 \\
\hline \multirow{4}{*}{2016} & Італія & 24465 & 28,69 & Російська Федерація & 11647 & 47,14 \\
\hline & Франція & 13174 & 15,45 & Країни СНД & 4399 & 17,81 \\
\hline & Грузія & 12169 & 14,27 & Грузія & 3131 & 12,67 \\
\hline & Інші & 35471 & 41,59 & Інші & 5529 & 22,38 \\
\hline \multicolumn{2}{|r|}{ Всього } & 85279 & 100 & & 24705 & 100 \\
\hline \multirow{4}{*}{$\begin{array}{c}2017 \\
\text { (за } 7 \\
\text { місяців) }\end{array}$} & Італія & 13227 & 28.50 & Російська Федерація & 8833 & 50.13 \\
\hline & Грузія & 7437 & 16.02 & Країни СНД & 3654 & 20.74 \\
\hline & Франція & 5545 & 11.95 & Грузія & 2323 & 13.18 \\
\hline & Інші & 20209 & 43.54 & Інші & 2810 & 15.95 \\
\hline \multicolumn{2}{|r|}{ Всього } & 46418 & 100 & & 17621 & 100 \\
\hline
\end{tabular}

Імпорт вин у 2016 році склав \$ 85,27 млн, що 1,5 рази більше, ніж роком раніше. У кількісному вираженні поставки також зросли з 23,3 млн літрів 2015 року до 43,1 млн літрів 2016 року. Примітно, що імпорт ігристих вин склав \$ 14,86 млн (2,73 млн л).

Основним імпортером вина в Україну третій рік поспіль залишається Італія (близько $30 \%$ всього імпорту). Поставки досягли \$ 24,46 млн (7,35 млн л). Французьких вин було завезено на \$ 13,17 млн $(2,73$ млн л). Грузія замикає трійку найбільших імпортерів вина в Україну. Ї̈̈ поставки склали \$ 12,16 млн $(4,58$ млн л). Відзначимо, що в 2016 році в топ-10 найбільших імпортерів вина увійшли такі нові країни, як Литва і Португалія потіснивши при цьому Аргентину та Австралію. Щодо експорту вина, то основним ринком збуту продовжує залишатися Російська Федарація (у 2016 році це складає 47,14\%, а за 7 місяців 2017 року $-50,13 \%)$.

Зазначені тенденції указують на зниження ємності ринку виноробної промисловості України (рис. 1).

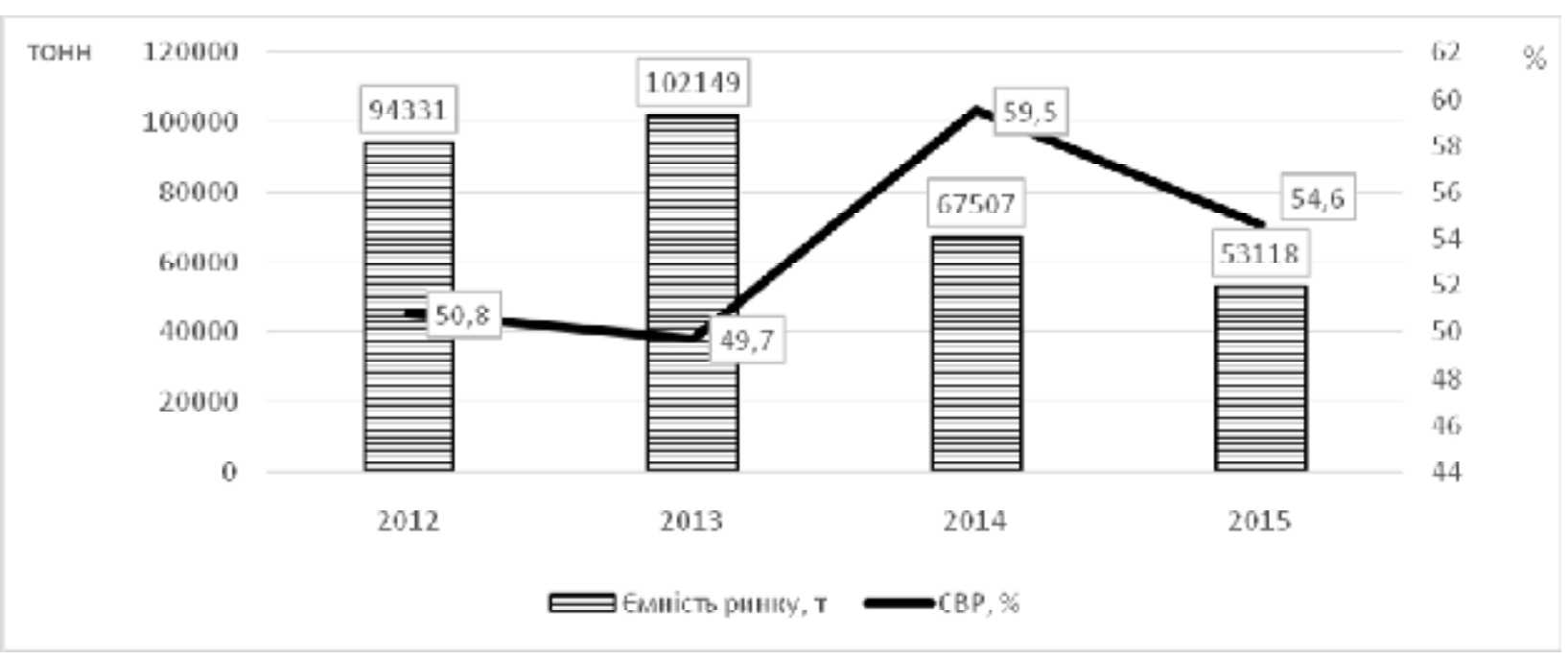

Рис. 1. Динаміка смності і ступеня відкритості ринку виноробної промисловості України* *авторське дослідження 
Маємо зниження ємності ринку виноробної продукції, ступінь відкритості даного ринку перевищує $50 \%$. Можна висунути припущення щодо впливу внутрішнього платоспроможного попиту країни та економічного потенціалу на ступінь відкритості вітчизняного ринку виноробної промисловості. 3 огляду на високий ступінь залежності попиту на виноробну продукції від кон`юнктури ринку, такий стан речей дуже загрозливий для вітчизняного виробника, оскільки маємо абсолютну незахищеність від імпортної продукції, більш конкурентоспроможної по ціні.

Що стосується вітчизняних виробників, то вони вимушені вести політику виживання. На це указує: (1) низький рівень рентабельності виробників, особливо малих і середніх підприємств, що пов'язано iз підвищенням вартості ліцензій (з 2016 року змінився порядок - не сплачують винороби, які використовують виноматеріали власного виробництва), (2) скорочення виноградних насаджень, (3) висока вартістю просування продукції на ринок, що пов`язано із значними транзакційними витрами, які є наслідком недосконалості ринкових механізмів та недостатнього державного регулювання економічних процесів, що відбуваються на підприємствах України.

На жаль, при відкритості і незахищеності українського ринку, частина покупців будуть відмовлятися від вітчизняного на користь європейського продукту, не завжди більш якісного, проте більш привабливого за ціною. В результаті продажі українського продукту можуть впасти, що в свою чергу загострить боротьбу з європейськими виноробами за українського споживача. Засобами такої боротьби може бути: підвищення якості, креатив, збільшення бюджетів на прямий доступ до покупця через фірмові дегустаційні зали, включення в туристичні маршрути залучення туристів на виноградники та виробничі потужності. Мета одна: донести до людей, наскільки важка та поважна праця виноградарів і виноробів, розповісти їм про вино і підвищити культуру пиття вина, навчити пити і розуміти вино, дати можливість самим переконатися, що в Україні $є$ фахівці і $є$ результат їхньої важкої праці, якими можна і треба пишатися, і яких потрібно цінувати. Вітчизняний споживач має робити усвідомлений вибір, а не вибір на користь іноземної упаковки.

Висновки та перспективи подальших досліджень. Систематичне нагромадження дисбалансів зовнішньої торгівлі сприяє нарощуванню імпортозалежності внутрішнього ринку виноробної галузі України, що веде до витіснення національного виробника. Антикризове регулювання вітчизняного виноробства має включати комплексний механізм забезпечення конкурентоспроможності продукції, в основі якого якість, креативність, ціна і конкретні маркетингові інструменти виявлення і задоволення потреби споживачів. В умовах гострої фінансової кризи, виноробні підприємства гостро потребують державної підтримки. У країнах ЄС садівнича та виноградновиноробна галузі отримують державну підтримку у вигляді дотацій або субсидій із спеціальних фондів, які існують для фінансування загальнодержавних i галузевих програм, створення багаторічних насаджень, технічного оснащення галузей, науководослідної діяльності у сфері садівництва та виноградарства. Державна підтримка вітчизняних виробників має носити характер програми антикризового регулювання розвитку виноробних підприємств.

По-перше, місцеві виробники повинні буди пріоритетними для держави, а отже мати привілеї у порівнянні з імпортною продукцією.

По-друге, це вже стосується виключно виноробів, необхідно офіційно визнати вино продуктом харчування та сільськогосподарською продукцією, а не алкогольним напоєм. Це світова практика, вино за кордоном (у визнаних виноробних країнах) - взагалі не є підакцизним товаром.

Інструментами антикризового регулювання виноробства мають стати: (1) впровадження високопродуктивних сортів винограду, (2) зростання продуктивності та якості продукції, (3) диверсифікація виробництва та ринків збуту, (3) освоєння інновацій, (4) просування вітчизняної продукції на зовнішні ринки тощо, без чого неможливий успішний розвиток галу3i.

Науковою новизною даного дослідження $€$ розробка комплексу засобів підвищення ефективності експортно-імпортної діяльності, до яких пропонується включити чітку державну політику щодо регулятивних механізмів забезпечення експортної спроможності виноробної галузі, що стає важливим інструментом захисту вітчизняного винороба від агресивної експансії зарубіжної винної продукції, що і буде напрямком подальших досліджень.

\section{Література}

1. Василенко В. О. Антикризове управління підприємством / В. О. Василенко. - Київ: ЦУЛ, 2003. - 504 с.

2. Коротков Э. М. Антикризисное управление: [учебник] / Э. М. Коротков. - [2-е изд., доп. и перераб.]. М.: ИНФРА-М, 2007. - 620 c.

3. Шершньова 3. С. Антикризове управління підприємством: [навч. посібник] / Шершньова 3. Є., Багацький В. М., Гетманцева Н. Д. - К.: КНЕУ, 2007. - 680 с.

4. Мельник Ю. М. Ситуаційне застосування маркетингових інструментів на різних стадіях антикризового управління / Ю. М. Мельник. - Донецьк: ДРУК - ІНФО, 2010. - С. 272 - 274

5. Маркетинг і менеджмент інноваційного розвитку: [монографія] / [за заг. ред. С. М. Ілляшенка].- Суми: ВТД «Університетська книга», 2006. - 728 с. 
6. Авідзба А. М. Удосконалення організаційно-економічного механізму розвитку виноградарськовиноробного комплексу України / А. М. Авідзба // Вісник аграрної науки: науково-теоретичний журнал української академії наук. - 2010. - №4. - С. 5-8.

7. Экономические проблемы виноградарства и виноделия / [под ред. академика НАН Украины Б.В. Буркинского]. - О.: Институт проблем рынка и экономико-экологических исследований НАН Украины, 2007. - 216 c.

8. Кучеренко В. М. Формування та розвиток аграрної ринкової інституції виноробної галузі : дис. канд. ек. наук : 08.00.03 «Економіка і управління національним господарством» / Кучеренко В. М. - К., 2016. - 257 с.

9. Гаркуша О. Ю. Комплексна оцінка збалансованості розвитку виноробних підприємств: науковометодичний аспект / О. Ю. Гаркуша, С. М. Смирнов // Економічний нобелівський вісник. - 2014. - №1. - С. 95103.

10. Стратегічний аналіз виноробних підприємств: орієнтири та конкурентна позиція: [монографія] / [Т. Л. Мостенська, В. М. Марченко, В. О. Нова та ін.]. - К.: Кондор-Видавництво, 2012. - 306 с.

11. У 2016 виробництво вина в Україні скоротиться на 30-35\% [Електронний ресурс]. - Режим доступу до pecypcy: http://agravery.com/uk/posts/show/u-2016-virobnictvo-vina-v-ukraini-skorotitsa-na-30-35

12. Державна служба статистики України. Збірник «Промисловість України у 2011-2015 роках» [Електронний ресурс] - Режим доступу до ресурсу: http://www.ukrstat.gov.ua.

13. Acemoglu D. Kindleberger C.P., It's all about different kinds of risk [Электронный pecypc] // The Режим http://www.economist.com/economics/by-invitation/guestcontributions/its_all_about_different_kinds_risk

14. Griffin D. Types of Business Risk [Электронный pecypc] // Chron Small Business - Режим доступа: http://smallbusiness.chron.com/types-business-risk-99.html

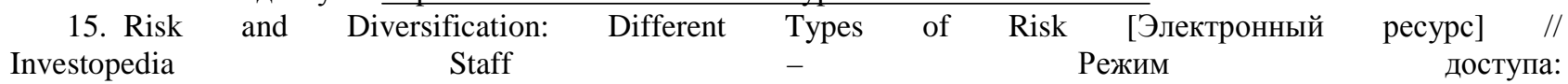
http://www.investopedia.com/university/risk/risk2.asp

16. Toth M., Piterkova A., Serences P. 2014. Non-financial factors' impact on profitability and riskiness of Slovak agriculture sector [Электронный pecypc] // Slovenská pol'nohospodárska univerzi$\begin{array}{lllll}\text { ta } & \mathrm{v} & \text { Nitre } & - & \text { Режим доступа: }\end{array}$ http://spu.fem.uniag.sk/Marian.Toth/publikacie/20149.pdf

17. Toth M., Serences P. The impact of different insurance types on the risk of wheat production in the Nitra region / M. Toth, P.Serences, //Acta oeconomica et informatica. - №2. - 2007. - p. 52-56.

18. The Orange Book: Management of Risk - Principles and Concepts / Her Majesty's Treasury on behalf of the Controller of Her Majesty's Stationery Office.United Kingdom. London, October 2004, 50 pages.

Стаття надійшла 11.10.2017

Стаття прийнята до друку 25.10.2017

Доступно в мережі Internet 30.12.2017

\section{Бондаренко С.A. кандидат экономических наук, старший научный сотрудник отдел экономического регулирования природопользования \\ Институт проблем рынка и экономико-экологических исследований НАН Украины \\ Французский бульвар, 29, г. Одесса, Украина, 65044 E-mail: lana.bond@ukr.net}

\section{Руммо B.B.}

кандидат экономических наук, доцент кафедра економической теории и финансово-економической безопасности Одесская национальная академия пищевых технологий

ул. Канатная, 112, г. Одесса, Украина, 65039 E-mail: etfeb@ukr.net

Низяева B.P.

магистрант

кафедра економики предприятия

Университет государственной фискальной службы Украины ул. Университетская, 31, г. Ирпень, Украина,08201

E-mail: viktoriyanizjaeva@gmail.com

\section{АНТИКРИЗИСНОЕ РЕГУЛИРОВАНИЕ ЭКСПОРТНО-ИМПОРТНОЙ ДЕЯТЕЛЬНОСТИ УКРАИНСКОГО ВИНОДЕЛИЯ}

У цій статті досліджується стан експортно-імпортної діяльності виноробної промисловості, проаналізовані тенденції, на основі яких виявлені характерні закономірності та поточні основні ризики, які необхідно враховувати для забезпечення належного рівня експортних можливостей галузі. Встановлено, що обсяги виробництва вин характеризуються чіткою тенденцією до зменшення. Так, в останні 
роки виробництво вина значно знизилося, значно знизився виробничий потенціал. Характеризується негативною тенденцією експортно-імпортна політики вина. Простежується чітка цінова дискримінація українських товарів на зовнішніх ринках - європейський ринок захищений від зовнішньої експансії. Аналіз показав позитивний баланс зовнішньої торгівлі внаслідок переваги експорту над імпортом. Державна експортно-імпортна діяльність виноробної галузі має розробити заходи для протидії посиленню зарубіжної експансії виробництва вин на внутрішньому ринку України, що становить реальну загрозу для існування вітчизняного виноградарства та виноробства. Ці тенденції вказують на зменшення розміру ринку виноробної промисловості. Доведено, що регуляторний вплив на розвиток виноградарства та виноробства має зосереджувати увагу, з одного боку, на безпосередній роботі з споживачем, створення його національної свідомості та усвідомлення вітчизняного виробництва виноробної промисловості, з іншого - реструктуризації імпорту. Розвиток державної підтримки виноробства України з урахуванням світового досвіду є важливим стимулом для розвитку ринку винограду та його продукції, що характеризується тенденцією до втрати. Спостерігається тенденція цінової переваги імпорту над експортом, звичайно, вимагає спеціальних заходів для протидії. Головними інструментами боротьби з європейськими виробниками за українських споживачів є якість, креативність, збільшені бюджети для прямого доступу до клієнта через фрірмові дегустаційні зали тощо.

Ключові слова: експортно-імпортна діяльність, виноробна промисловість, розмір ринку, ступінь відкритості ринку вина, антикризове управління.

\section{Bondarenko S.}

Ph.D. in Economics, Senior Researcher Department of Nature Economic Regulation Institute of market problems and economic \& ecological research

of National Academy of Sciences of Ukraine Frantsuzskiy boulevard, 29, Odessa, Ukraine, 65044

E-mail: lana.bond@ukr.net

\author{
Rummo V. \\ Ph.D., Associate Professor \\ Department of Economic Theory \\ financial and economic security \\ Odessa National Academy of Food Technologies \\ Kanatna str., 112 , Odessa, Ukraine, 65039 \\ E-mail: etfeb@ukr.net
}

\author{
Niziaeva V. \\ Undergraduate \\ Department of Business Economics \\ University of Public Fiscal Service of Ukraine \\ Universitetska str., 31, Irpin, Ukraine, 08201 \\ E-mail: viktoriyanizjaeva@gmail.com
}

\title{
ANTICRISIS REGULATION OF EXPORT-IMPORT ACTIVITY OF UKRANIAN WINE-MAKING
}

This article explores the state of export and import activities of wine industry, analyzes trends on the basis of which characteristic patterns and current major risks that must be considered to ensure an adequate level of export capacity of the industry are revealed. It has been established that the volumes of wine production are characterized by a clear tendency to decrease. Thus, in recent years the production of wine has decreased significantly, the production potential has significantly reduced. Export and import wine-making activity is characterized by the negative trend. The price discrimination has been traced, the Ukrainian products are not presented well enough in the foreign markets - the European market is protected from external expansion. State mechanisms of management of export and import activity of wine-making branch must include measures against intensifying foreign expansion of wine-making in the domestic market of Ukraine, that presents a real threat to existence of domestic wine growing and winemaking. It has been proved that the regulatory effect on the development of wine-growing and wine-making must be focused on the one hand, on the direct work with consumers, on the other hand, on the import restructuring. The development of the state support of Ukrainian wine-making industry, taking into account the international experience, is an important motive for development of grape market and its products, which are characterized by the tendency to loss. The observed tendency of the import price advantage over export one, certainly, requires special measures for counteraction. The main tools of struggle with European winemakers for Ukrainian consumers are: quality, creativity, increase of the budgets for direct access to the costumer through own tasting rooms, attraction of the tourists to vineyards and production objects, creation of hiking trails. Thus, the main purpose of education is the necessity of domestic consumers and improvement of the wine-making culture, so that Ukrainian consumers should make a proper choice of domestic production.

Key words: export and import activity, wine industry, market size, the degree of openness of wine market, anti-crisis management. 


\section{References}

1. Vasylenko, V. O. (2003). Antykryzove upravlinnia pidpryiemstvom. Kyiv: TsUL.

2. Korotkov, E. M. (2007). Antikrizisnoe upravlenie (2-e izd., dop. i pererab. ed.). M.: INFRA-M.

3. Shershnova, Z. Ie., Bahatskyi, V. M., \& Hetmantseva, N. D. (2007). Antykryzove upravlinnia pidpryiemstvom. K.: KNEU.

4. Melnyk, Iu. M. (2010). Sytuatsiine zastosuvannia marketynhovykh instrumentiv na riznykh stadiiakh antykryzovoho upravlinnia. Donetsk: DRUK - INFO.

5. Illiashenko, S. M. (Ed.). (2006). Marketynh i menedzhment innovatsiinoho rozvytku. Sumy: VTD «Universytetska knyha».

6. Avidzba, A. M. (2010). Udoskonalennia orhanizatsiino-ekonomichnoho mekhanizmu rozvytku vynohradarskovynorobnoho kompleksu Ukrainy. Visnyk ahrarnoi nauky: naukovo-teoretychnyi zhurnal ukrainskoi akademii nauk, (4), 5-8.

7. Burkinskiy, B. V. (Ed.). (2007). Ekonomicheskie problemyi vinogradarstva i vinodeliya. O.: Institut problem ryinka i ekonomiko-ekologicheskih issledovaniy NAN Ukrainyi.

8. Kucherenko, V. M. (2016). Formuvannia ta rozvytok ahrarnoi rynkovoi instytutsii vynorobnoi haluzi. Kyiv.

9. Harkusha, O. Iu., \& Smyrnov, Ie. M. (2014). Kompleksna otsinka zbalansovanosti rozvytku vynorobnykh pidpryiemstv: naukovo-metodychnyi aspekt. Ekonomichnyi nobelivskyi visnyk,(1), 95-103.

10. Mostenska, T. L., Marchenko, V. M., \& Nova, V. O. (2012). Stratehichnyi analiz vynorobnykh pidpryiemstv: oriientyry ta konkurentna pozytsiia. K.: Kondor-Vydavnytstvo.

11. U 2016 vyrobnytstvo vyna v Ukraini skorotytsia na 30-35\%. (2015, December 07). Retrieved from http://agravery.com/uk/posts/show/u-2016-virobnictvo-vina-v-ukraini-skorotitsa-na-30-35

12. Derzhavna sluzhba statystyky Ukrainy. Zbirnyk «Promyslovist Ukrainy u 2011-2015 rokakh». (2016). Retrieved from http://www.ukrstat.gov.ua

13. Acemoglu, D., \& Kindleberger, C. P. It's all about different kinds of risk. Retrieved from http://www.economist.com/economics/by-invitation/guestcontributions/its all_about different_kinds risk

14. Griffin, D. Types of Business Risk. Retrieved from http://smallbusiness.chron.com/types-business-risk-99.html

15. Risk and Diversification: Different Types of Risk Diversification: Different Types of Risk. Retrieved from http://www.investopedia.com/university/risk/risk2.asp

16. Toth, M., Piterkova, A., \& Serences, P. (2014). Non-financial factors' impact on profitability and riskiness of Slovak agriculture sector. Retrieved from http://spu.fem.uniag.sk/Marian.Toth/publikacie/20149.pdf

17. Toth, M., \& Serences, P. (2007). The impact of different insurance types on the risk of wheat production in the Nitra region. Acta oeconomica et informatica, (2), 52-56.

18. The Orange Book: Management of Risk - Principles and Concepts . (2004). London: Her Majesty's Treasury on behalf of the Controller of Her Majesty's Stationery Office.

Received 11 October 2017

Approved 25 October 2017 Available in Internet 30.12.2017 